\title{
Cururu e Siriri: entre naturalistas, viajantes e folcloristas
}

\author{
Marta Martines Ferreira \\ Doutoranda em Arte e Cultura Contemporânea \\ Universidade do Estado do Rio de Janeiro
}

Resumo: Este artigo traz notas e observações sobre os relatos de viajantes, naturalistas e folcloristas a respeito das danças de Cururu e Siriri, em Mato Grosso, no período de 1879 a 1976. Percorrer os caminhos traçados por esses relatos, é trazer à tona memórias silenciadas, dando voz e reconstituindo histórias de vidas renascidas. As impressões sobre esses lugares, esses povos e suas culturas, se apresentam sob os mais variados ângulos e opiniões.

Palavras-chave: Cururu e Siriri; Memórias; Culturas. 


\title{
Cururu y Sirirí: entre los naturalistas, viajeros y folkloristas
}

Resumen: En este artículo se trae notas y observaciones sobre los informes de los viajeros, naturalistas y folcloristas sobre los bailes del Cururu y Sirirí en Mato Grosso, de 1879 a 1976. Ir a través de las trayectorias trazadas por estos informes, es para traer memorias silenciadas, dando voz y la reconstitución de las historias de vida renacer. Las impresiones de estos lugares, estas personas y sus culturas, están presentes en los más variados ángulos y puntos de vista.

Palabras clave: Cururu y Siriri; Recuerdos; Culturas.

\section{Cururu and Siriri: among naturalists, travelers and folklorists}

\begin{abstract}
This article presents notes and observations on the reports of travelers, naturalists and folklorists about the dances of Cururu and Siriri, in Mato Grosso, from 1879 to 1976 . To traverse the paths traced by these accounts is to bring to the surface silenced memories, giving voice and reconstituting stories of reborn lives. The impressions on these places, these peoples and their cultures, come under the most varied angles and opinions.
\end{abstract}

Keywords: Cururu and Siriri; Memoirs; Cultures. 


\section{Introdução}

A história da humanidade é permeada de conquistas, conflitos, expropriações, mitos heroico-fundadores e são registradas, quer pela necessidade de preservar tradições, quer por idealizações identitárias. Entretanto, outras histórias não são registradas, já que não são cotadas como relevantes, mas que por outro lado, ajudariam a esclarecer certas invenções históricas presentes no imaginário coletivo.

Grande parte dos estudos sobre a trajetória das danças no Brasil, busca o começo, o sinal inicial1. No entanto é possível identificar o primeiro relevo histórico, a história não contada? Ou, apreender algo sobre o cururu e o siriri de hoje, olhando para um passado tão remoto? Neste contexto, cabe aqui apontar o trabalho de Maria Laura Cavalcante (2012), que analisou em profundidade e criticidade, alguns estudiosos que se debruçaram em investigar o sincretismo e ou a justaposição de religiões afro-brasileiras, em uma "busca de origens" (p. 39), continuidades ou apropriações. Suas reflexões em Origens para que as quero? traz como ponto central, do ponto de vista das "transformações e perdas" (p. 42) ou nas palavras de Nina Rodrigues a "degeneração da pureza primitiva" (apud, p. 42), a indagação de que, seria o puro, uma garantia de fidelidade das práticas sociais, às origens? e ainda, seria possível definir o "núcleo original de crenças e práticas" (p. 51) centenárias? A autora aponta na pesquisa de Roger Bastide, a instauração de um tema extremamente atual, qual seja, transpostas as fronteiras da vida pessoal e cotidiana pela interação urbana, "trata-se de saber como sistemas de pensamento e práticas rituais preexistentes atualizam-se em novos contextos históricos e sociológicos" (p. 53), como se modificam e interagem com as forças da modernidade.

Desta feita, tentar estabelecer um quadro histórico do cururu e siriri, seria mais prudente começar precisamente com a colonização do Brasil. É evidente que os portugueses trazem na sua história, um heterogêneo panorama cultural ibérico, em ampla combinação hispânica-tradicional, hispânica-romana, as celtas, suevas e godas (barbaras), as cristãs, as judias, as árabes e galaicoportuguesa2. Esses povos não só miscigenaram, como assimilaram as danças dessa população, como teriam trazido e cedido as suas próprias.

Buscar o elo para entender as descrições físico-sonoras e históricas destas danças, parece um exercício inesgotável e é válido lembrar que um início sempre nos leva a outro mais longínquo, que nos remete a outro e outro. A restauração da origem é profundamente histórica e não se cumpre somente no retorno às fontes, mas também pelo estabelecimento de uma nova ligação entre passado e presente. Nesse labirinto, é possível encontrar outros múltiplos e paralelos caminhos iniciais. Todavia, ao revelar os discursos e os contextos que

1 “As origens são um começo que se explica”. Bloch nos alerta ainda sobre o papel do historiador, deve-se ter o cuidado para não ignorar "a imensa massa dos testemunhos não-escritos" (BLOCH, 2002. pp. 26/24).

2 Jose Sarpostes - seu trabalho não é propriamente um trabalho etnológico ou folclórico - mas um importante estudo sobre as danças em Portugal. 1970. 
foram, ora moldando, ora transformando o lugar destas danças, é passível de justificar e compreender inclusive, mudanças físicas e sonoras.

Sob a ótica dos colonizadores, etnólogos, folcloristas e viajantes estrangeiros, temos acesso a certa documentação, senão farta, ao menos nos sugere um vasto universo simbólico associado às danças em terras brasileiras. Várias são as análises e narrativas a respeito das festas, das danças e do cururu, textos que atribuem sentido a essa arte do fazer, expressão que representa a cultura tradicional do Estado de Mato Grosso e partes do Estado de Mato Grosso do Sul e áreas do médio Tietê paulista. Configurações que perpassam da dança religiosa recreativa à modalidade caipira, supostas a partir da vinculação de tempo e lugar, segundo suas relações de poder.3

\section{A eloquência dos relatos e seus múltiplos olhares}

1869. O português Joaquim Moutinho não só passou pela região, ele morou e criou raízes por aqui, presenciou algumas das tragédias que assolaram a população cuiabana, como a invasão das tropas paraguaias em 1864, a grande enchente do rio Cuiabá em 1865, "que subiu a tão altas proporções o rio Cuyabá, que, trasbordando do seu leito, inundou a florescente e bela freguesia de Pedro II, deixando a maior parte de suas casas arrasadas, e causando assim grande prejuízo à Provincia" (p. 9). Mais tarde em 1867 uma epidemia causada pela bexiga e sentiu na pele a animosidade popular contra os estrangeiros em 1834, que ficou conhecida por Rusga. Demonstra especial predileção pela vida musical da província, no qual registrou que essa era "dominante entre homens e senhoras" (p.18). Menciona a presença de dezesseis pianos na cidade, nos locais de convívio familiar. Nas suas crônicas estão os mais antigos relatos produzidos em Mato Grosso, com relação ao cururu e a viola até então, cocho, seu principal instrumento musical acompanhante.

Não obstante, ao observar o cururu deixa claro seu estranhamento e reprovação, pois era praticados pela população pobre, classificando-o de "o mais insípido e extravagante divertimento a que temos assistido depois da dança dos bugres (índios). Formam uma roda de homens, um dos quais toca o afamado cocho e volteando burlescamente cantam a porfia numa toada assaz desagradável de versos improvisados" (p.19)". Ao som da viola-de-cocho a qual nomeia de grosseira, chamada de cocho (cotcho no linguajar cuiabano), juntamente com o adufo e tambor, dançam durante toda a noite regados à cachaça, esses cantores "sui generis" (p. 19)" amanhecem o dia em completa embriaguez. O cururu dos cuiabanos, segundo ele, era uma dança do gosto de "classes baixas e a gente do campo" (p.19). Conclui, "achamos originais estes folguedos, que sempre se dão quando festejam algum santo" (p. 20). Não deixa de registar o batuque, cuja descrição aponta como uma dança tão exageradamente ruidosa e que desperta certo frenesi.

3 Para Certeau o "poder tem sua lógica (...) o discurso ideológico se ajusta a uma ordem social (...) É um mesmo movimento que organiza a sociedade e as "idéias" que nela circulam” (CERTEAU, 1982. p. 69). 
1872/1887. O botânico João Barbosa Rodrigues (1890) em suas expedições pelo Amazonas, registra um determinado canto entre variadas etnias indígenas, que apesar de não relacionar diretamente ao cururu, confirma a representação mítica da dança do sapo (cururu) entre os nativos. Como explica Rodrigues as cantigas que coletou, fazem parte de um conjunto de fragmentos ligadas às festas portuguesas, São Thomé e São João, um canto, uma saudação religiosa denominada Çairé, de tantas que se perderam no tempo. As danças tapuias tinham o nome yuiá mo uauaka4, simulando o movimento dos animais. Quando se festeja para pagamento de promessa, arrumam um altar dentro de casa com a imagem do santo milagroso. Preparam uma grande tenda onde é servido o jantar aos convidados e fazem-se as danças. Durante a procissão as mulheres inclinam o çairé 5 ora para frente, ora para traz, saltando de um lado para o outro cadenciando os movimentos e os saltos. As festas duravam de três a quatro dias. Os versos coletados pelo pesquisador em tribos do Rio Solimões, segundo o viajante, por si só evidenciam a representação mítica do sapo nessas danças indígenas,

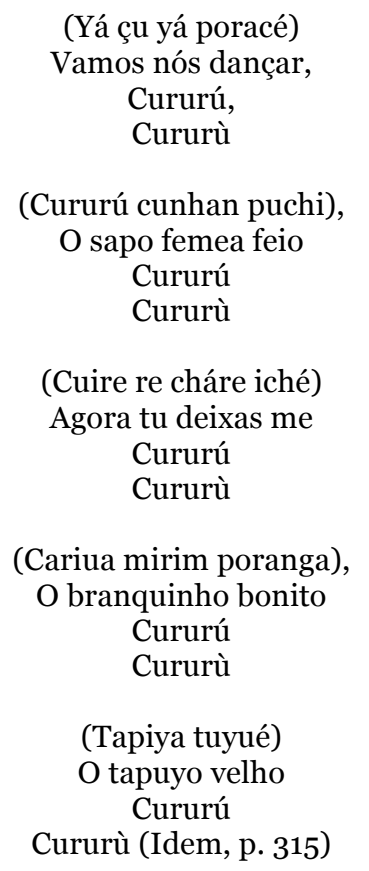

De acordo com Rodrigues Barbosa "o que resiste ao tempo e ainda se vê é o elemento africano fundido no nacional” (p. 276), principalmente pelo que é possível presenciar nos sítios do interior por "ocasião das festas de santo, formase o jongo ou batuque com o gambá e o krakachá" (id., grifo do autor), são o gambá (tambor) e o krakachá ou kanzá, instrumentos africanos, que o indígena

\footnotetext{
4 Tinham esse nome as danças tapuyas. Significa fazer (mo) revirar (uauaka) os braços (yiuá ou yibá). Segundo o autor daí veio, a abreviatura de chiba usado pelos caipiras do sul, usada por Silvio Romero, "a função popular que o som da viola, do pandeiro e do improviso, ama-se, dança-se e bebe-se” (RODRIGUES, 1890, p.275/276).

5 Instrumento em semicírculo de madeira, contendo dentro dois outros círculos menores, colocados um a par do outro, dessa união forma-se um raio grande que ultrapassa o círculo formando uma cruz. Instrumento inventado pelos jesuítas para perpetuar o cristianismo entre os indígenas, significando a Santíssima Trindade (RODRIGUES, Op. Cit. p. 280).
} 
incorporou às suas danças, mas que "a viola portuguesa aceita no Sul, no Amazonas foi rejeitada" (ibid.).

Seguindo a linha de raciocínio das pesquisas de Barbosa, uma explicação pode-se supor bem razoável, é a adaptação da palavra cruz pelas diferentes tribos e sotaques e diversas influências de pronúncias, "porque quem aprende a língua tapuyo ou branco, já bebe as primeiras gotas em fontes viciadas" (p. X), devido ao "grande número de missionários, todos sotaques diferentes, que ensinaram a língua nheengaibas, plantando sementes degeneradas em terrenos de natureza diferente, o que deu em resultado uma corruptela geral não só em pronuncia, como em significados6”. Uma língua em construção, com dialetos carregados de sutilezas, em um território onde conviveram, índios, espanhóis, holandeses, alemães, franceses e africanos. Para o autor essa confusão acabou por corromper a linguagem primitiva, influenciadas sobretudo, pelas designações formadas nas acomodações migratórias e que Tupi, Tupi austral, Guarani e Onagua, descendem de uma mesma origem. Considera que a presença dos missionários trouxe uma divisão que "se estabeleceu, devida a influência da pronúncia espanhola e portuguesa, vindo a da pronúncia das tribos Nheengaibas e a dos Padres portugueses acabar a separação, fazendo com que o Guarani não entendesse o Tupi, e vice-versa" (p. VIII). É nesse cenário que ocorre a sedimentação da língua portuguesa, sobretudo com a chegada dos portugueses ao Brasil a partir de 1500.

Acrescenta-se à essa ideia, o fato de que as designações de identificação da terminologia tupi-guarani, cuja dicionarização coube aos jesuítas7, passam "necessariamente, pela referência direta a, pelo menos, cinco idiomas: o latim; o espanhol; o galego-português; o tupi-guarani (além de outras línguas ou dialetos nativos); e o português arcaico" (AMORIM, 2015, p. 35). Um processo de transformação e incorporação em que, curuçá, curussé ou curuzu, para cururu nos parece uma hipótese bem razoável (id, p. 33)8. Sem reconhecer as conexões que essas línguas fazem com o português atual, a compreensão das terminologias se tornam mais difíceis o que pode limitar nosso entendimento sobre o espectro das práticas sociais em torno dessas danças.

1887/1888. Karl Steinen (1912), ao comentar sobre a musicalidade da população cuiabana, cuja presença nesta região se fez em 1884, aponta as bandas de música militares que se revezavam nas atividades das celebrações oficiais e religiosas, confirmando o que nos disse Moutinho sobre a musicalidade do povo cuiabano. Essas bandas, eventualmente atuavam no

\footnotetext{
6 Barbosa Rodrigues ainda acrescenta que, depois de 1549 começaram as Missões no Brasil, vindo para cá nesse mesmo ano o Padre Manoel da Nobrega como superior e consta dessa data o ensino da língua vernácula, que mais tarde começou a ser escrita pelas missionários portugueses, espanhóis e franceses, quase ao mesmo tempo. Cada qual definiram gramaticas, vocábulos e compêndios, conforme lhes soava aos ouvidos e que os ajudariam a se fazer entendidos pelos nativos (RODRIGUES, Op. Cit. p. XI).

7 Telmo Verdelho afirma que no âmbito da informação gramatical "a lexicografia da língua portuguesa, como a dos restantes vernáculos europeus, nasceu dos vocabulários bilíngues que puseram em confronto o latim e as línguas vulgares”. A referência dicionarística e a produção lexicográfica, que coube aos jesuítas instalados em Portugal desde o século XVI. Responsáveis pela produção de manuais escolares voltados para a formação linguística. Entre eles a produção das línguas de missão no Brasil e no Oriente. VERDELHO, Telmo. Dicionários Portugueses, Breve História. (NUNES, 2002, p. 17).

8 O português se sedimenta com a publicação das primeiras gramáticas e dicionários e começa a adquirir muitos dos traços atuais, dando início à chamada “fase moderna” da língua (do séc. XVI em diante).
} 
teatro em participação nas representações dramáticas encenadas na sede da sociedade cultural Amor à Arte, além de se dedicarem à promoção de chás dançantes e saraus literomusicais, voltados para a elite local, "à noite toda a cidade dançava" (p. 92). E conclui, "não é possível que haja uma outra cidade no mundo onde se toque mais música, se dance mais e alteiem mais frequentemente os estandartes da procissão" (p. 68). Suas descrições sobre o cururu, seguem a linha dos relatos de seus contemporâneos no que diz respeito ao estranhamento. Aponta o cururu como uma dança preferida entre os habitantes do Mato Grosso e a descreve como uma dança de roda, na qual todos fazem parte da festa. Canta-se em louvor ao santo e quem, ao passar diante do altar faz uma genuflexão.

Dança, que de acordo com o viajante era acompanhadas de caracachás (ganzá) espécie de reco-reco feito de bambu, violinos, tamborim e muitas vezes a marimba. Logo após a louvação cantam em honra ao rei e rainha da festa, cujas toadas tratavam dos mais variados assuntos, desde a devoção católica aos de "amor, zombaria e outros inventados conforme as inspirações do momento" (1940, p. 711)9. Destaca-se aqui o pioneirismo da descrição do canto e dança do cururu, depois dos relatos presentes nas crônicas de Moutinho em 1869. Steinen ainda menciona duas outras danças de origem africana, uma descrita como dança dos animais e a outra uma festa de máscaras. Menções que se relacionam com duas representações folclóricas presentes no Estado, a primeira supõe-se ser a dança do Boi-a-serra, ou Bumba-meu-boi, ou Boi-bumbá em outras regiões. A segunda supõe-se ser a Dança dos Mascarados, que integra as celebrações do Divino em algumas regiões do Estado.

1897. Couto de Magalhães em suas viagens pelo Brasil, diga-se, um crítico contumaz das atrocidades praticadas aos índios, apresenta o cururu como mais uma dança religiosa para os tupis e guaranis. E que apesar de não terem sido registradas pelos jesuítas e serem depreciadas pela nobreza, suas músicas de "toadas, profundamente melancólicas dessas músicas e a dança, forão adoptadas pelos jesuítas, com o profundo conhecimento que tinhão do coração humano, para as festas do divino Espirito Santo, S. Gonçalo, Santa Cruz, S. João e Senhora da Conceição" (p. 27), usadas na catequização e atração ao cristianismo. Sem maiores detalhes, apresenta as regiões citadas, São Paulo, Bahia, Minas, Goiás e Cuiabá. Aponta a viola de três cordas, feitas de tripa, como instrumento indígena. Comenta sobre o fato da proibição de se dançar sem licença da polícia o que "equivale a ser dispersado a força, ou ir para a cadeia” (p. 31). Em sua obra O Selvagem (1876), na descrição destes sertões, reconhece nos cuiabanos uma inclinação natural para a diversão, considerandoos à época, muito parecidos fisicamente com os paraguaios e "grandes cantores e amigos de dança como todos os povos [e muito] unidos aos indígenas" (p. 167).

1900. Max Schimidt (1942) observou a dança no município de Rosário Oeste ao norte de Cuiabá, habitado à época pelos índios Borôros e também em

${ }_{9}$ Supõe-se que o violino mencionado seja o dedilhado, considerando que não mencionou arco na sua execução. 
Amolar, um dos 6 distritos de Corumbá, hoje Mato Grosso do Sul, na fronteira boliviana, habitada à época pelos índios Guató, por ocasião das festas de final de ano. Registrou,

\begin{abstract}
Reginaldo havia trazido de Amolar uma enorme garrafa de aguardente. Dessa maneira o cururu começou logo, dança essa que já conhecia de Rosário e que agora muito me acabrunhava, pois não poderia descansar depois das peripécias do dia. Todos fizeram círculo, João Caracará afinou a viola, alguns pratos serviram de pandeiros para as colheres e, logo depois, ouviram-se os gemidos das vozes que entoavam os versos uníssonos. $\mathrm{O}$ andar regularmente ritmado em círculo era de momento a momento interrompido por uns pulos executados pelo nosso amigo Reginaldo, que ainda procurava completar o ruído dos chamados instrumentos, batendo com as palmas das mãos nas diferentes partes do corpo propícias a isso (p. 109/110).
\end{abstract}

E enquanto "a viola e o canto lá na floresta soavam de longe aos meus ouvidos, os índios preparavam-se de novo para um cururu (...)” (p. 123). Já em Cuiabá, participou de uma festa à Imaculada Conceição, a qual assim descreve,

\begin{abstract}
No interior da casa foi erigida uma espécie de altar em caixote de vidro com diversas imagens de santos, havia sido enfeitado com papel de cor e fitas de pano: diante dele ardiam duas grandes velas (...). Pouco depois fez-se um intervalo em que foi servida aguardente e, então, agrupou-se em torno de altar certo número de dançantes, formando semicírculo para começar a dança do "cururu", tão conhecida em Mato Grosso. Parte dos que dançavam acompanhava na "viola" os versos ali mesmo improvisados pelos cantores. Outra parte dos presentes seguia o ritmo por meio de um pau que roçava numa ripa de bambu, instrumento que denominavam "caracaxá" (p. 14).
\end{abstract}

Segundo o etnólogo, o siriri e o cururu eram muito apreciados em Mato Grosso e eram dançados não só pela "população escura”, mas por "pessoas de todas as gradações de cor” (p. 11). A formação inicial era em fileiras, para em seguida se formar o círculo, de frente para o altar, em que animados pelos movimentos de revoltear entre si, varavam dançando e cantando noite adentro, estimulados pela aguardente de cana. Qual sua surpresa "enquanto se dançava o cururu dentro de casa, lá fora se realizava outra espécie de dança, muito apreciada em Mato grosso, o ciriri (sic), acompanhado também por música e versos cantados” (p. 14). Apesar de afirmar ser essas danças do gosto do cuiabanos, o etnólogo não apresenta maiores detalhes sobre os brincantes. Consta ainda no seu livro, uma fotografia da viola, praticamente idêntica à que atualmente acompanha as rodas de cururu e siriri. Presenciou ainda nos festejos de Rosário, a dança do Congo, até hoje praticada em algumas regiões do Estado.

1921. Cornélio Pires (2002) ao falar sobre o cururu paulista, classifica-o como "dança (...) dos poetas sertanejos, (...) formando roda e cantando, cada um por sua vez atirando seus desafios mútuos (...), os cururueiros cantam sem mostras de cansaço, desde o anoitecer até o amanhecer, os instrumentos são pandeiro, adufe e a célebre viola (...) uma dança mista do africano e do bugre" (p. 109). Enfatiza-a como dança, formada em círculos.

Em outro trecho ressalta o caráter religioso da dança, em que festeiros cantam em frente para o altar da sala da casa. Conta ainda que após o momento solene a festa ganha outro tom, torna-se em desafios mútuos. A Festa do Divino, nos versos do Poema: Noivo Caipira e Paixão impossível, um retrato da vida campestre, 
No cururu manhoso, a caboclada

Rasga nas violas, canta ao desafio,

Provocando constante gargalhadas

No pouso do divino

Fremente, o cururu não falta no

Folguedo ...

Ressoa pela mata o estrondo da roqueira1o.

1925. O folclorista Antônio Americano do Brasil (1973), apresenta, entre outras danças, o cururu na região de Goiás, como "uma dança em que dois violeiros mostram (...) a habilidade de rimar sobre diversos assuntos (...) em roda, palmas e sapateados" (264). Essa referência ao cururu na região, até onde as leituras apontam, é a referência mais conhecida da ocorrência da dança naquela região. Talvez a única.

Esses relatos de folcloristas e etnólogos que se dedicaram a mapear o Brasil, nos permitem uma visualização da cartografia da área de difusão deste gênero cultural, entretanto, tão pouco é possível afirmar um processo de transformação ou desaparecimento em determinadas regiões.

1942. Mario de Andrade endossa as palavras de Couto de Magalhães quando afirma que

\begin{abstract}
Certas festas populares, religioso-coreográficas, tais como a dança de São Gonçalo e a dança de Santa Cruz, pelo menos nos arredores de São Paulo, após cada número do cerimonial, dança-se um Cururu. Ora os processos coreográficos desta dança tem tal e tão forte sabor ameríndio, pelo que sabemos de danças brasílicas com a cinematografia atual, que não hesito em afirmar ser o Cururu uma primitiva dança ameríndia, introduzida pelos jesuítas nas suas festas religiosas, fora (e talvez dentro) do templo (p. 137).
\end{abstract}

E conclui que sob forte influência portuguesa, juntamente com a força rítmica dos tambores africanos, a cultura brasileira se enriqueceu de termos "sonorosos" (p. 139) e danças variadas, cujos desafios cantados, com ritmo discursivo, era constante entre os ameríndios.

1947. João Chiarini (1949) ao estudar o folclore brasileiro, contesta a ideia da herança puramente indígena do cururu. Para o autor trata-se de uma dança de volteios e flexão de pernas, importada dos salões portugueses e que miscigenou interior adentro, tornando-se "mais puro, mais indígena" (p. 87). O autor assegura que o cururu surgiu na Bahia, sede do governo geral do Brasil no século XVI, originário do trovadorismo ibérico e provençal da idade média, característicos dos festejos portugueses, cuja migração se deu nos dois primeiros ciclos econômicos; pau-brasil e açucareiro. Absorvido pelo cristianismo jesuítico que "dominou-as, transformou-as, humanizou-as em folguedos em honra e glória de S. João Batista” (fl. o1). Para o autor, o português lutava e escravizava, o índio defendia-se, fugia ou ficava cativo e o africano trabalhava duramente, restavam-lhes apenas o canto. Cada um com

10 PIRES, Cornélio. Musa Caipira - As Estrambóticas Aventuras do Joaquim Bentinho (o Queima-Campo). Edição Comemorativa do CENTENÁRIO de nascimento do autor (1884-1984). Tietê (SP): Prefeitura Municipal de Tietê. Patacoadas. Itu, SP: Ottoni Editora, 2002. Poemas: Noivo Caipira e Paixão Impossível. 
suas referências sociais e todas amalgamadas e fundidas em um só molde. Portanto "o cururu [seria] uma canturia luso-afro-indígena” (fl. 1011).

1956. Antônio Candido, em seu artigo intitulado, Possíveis raízes indígenas de uma dança popular, afirma que é uma dança praticada por "caboclos de São Paulo, Goiás e Mato Grosso” (p. 1). Ao comentar sobre a ideia de sua herança indígena das tribos tupi, alerta que sendo o cururu derivado de uma dança indígena, quais seriam suas verdadeiras características? Analisa o trabalho de Mario de Andrade, Herbert Baldus e João Barbosa Rodrigues, traça alguns paralelos e apresenta alguns pontos a serem discutidos. Um dos pontos estaria justamente no fato de que cururu, na língua tupi, é um nome comum dado ao sapo, naturalmente engolidor de fogo, e confirmada por Herbert Baldus (1937) que recolheu entre os Guarani do litoral paulista o relato de um ancião da aldeia que afirma que aprendera com seus pais que "o sapo nos trouxera o fogo que São Pedro recebera de Deus. São Pedro não queria dar fogo aos Guarani. Então caiu uma faísca que o sapo engoliu e transmitiu aos Guarani" (p.213) e acrescenta,

\footnotetext{
O roubo do fogo por animais é um motivo espalhado na América do Sul. Ora é a raposa a ladra da faísca, ora o sapo. O sapo sempre o é nas tribos da grande família linguística dos Tupi. Que ele haja sido o escolhido para tal papel é muito compreensível porque como se sabe, este animal tem a capacidade singular de engolir coisas ardentes, como cigarros e brasas, talvez porque os torne pirilampo" (p. 213).
}

Herbert Baldus, presencia também em uma tribo tupi dos Guajajára no Maranhão outra dança do sapo, cuja representação "do roubo do fogo numa dança de kururú" (p. 215) e assim descreve;

\begin{abstract}
Recomeçou o canto; quando se tornou mais alto, o chefe da tribo levantou-se, dançou alguns passos e sentou-se novamente. Então trouxeram-lhe um gigantesco cachimbo no qual ele chupou algumas vezes. Mais fogosamente repetiu a dança, enquanto eu aproveitava para experimentar o pito. Não me dei muito bem com a cachimbada, porque os nervos da cavidade bucal me ficavam imediatamente afetados. A cada intervalo do baile punha-se o chefe a cachimbar. Que isto lhe era necessário evidenciou-se depois. Ateou-se fogo ao redor do qual os rapazes morenos pulavam em estado de embriaguez completa. De repente o chefe acocorou-se e pôs-se a saltitar pelo fogo a soltar o hu, hu, hu, do sapo. Depois tomou uma brasa e pondo-se a assopra-la, engoliu-a devagar. Isso foi o ponto culminante do baile mas não o único. A dança durou, quase sem interrupção, toda a noite. E sempre se repetia a cena do engolidor de brasa (p. 216).
\end{abstract}

Essas danças, de acordo com Candido, foram observadas também em tribos de Goiás e Mato Grosso, cada qual com suas próprias características e acrescenta que não há registro na representação de tais mitos, como "danças do sapo em tribos não-tupi” (p. 03), situação que segundo o folclorista, provém do contato acentuado ente colonizadores e tribos do grupo Tupi-Guarani. Cita ainda o folclorista João Ribeiro (1919), que no seu Folk-lore, faz a descrição da dança, cuja opinião se baseava em um rito fúnebre em tribo de Mato Grosso, "entre os bororós de Matto Grosso a cerimonia ritual e funerária que chamam bacururú, o que é celebrada entre clamores e algazarra grande. As palavras bacururú e cururu têm radicais comuns. Não é inverossímil que dos bororós tenha vindo o nome da dança do cururu" (p. 230), todavia, para Candido, havia 
o pesquisador se confundido, pois essa seria a dança dos bacururu, sem qualquer relação com o cururu,

Cururu é, como vimos, palavra tupi, e nada tem a ver com a referida cerimônia, cujo nome verdadeiro é "róia Kurireu", ou "canto grande", iniciada com uma imprecação em que surge o nome de um dos heróis civilizadores dos Borôro, os gêmeos míticos Bakororo e Itubore: a-a o-o Bakororo Kai re (p. 04).

Entretanto, Basilio de Magalhães (1919), em seu livro; Vocabulário-Língua dos Borôros-Coroados do Estado de Mato Grosso, assim define o vocábulo, Bacorôro - "canto, quer fúnebre, quer alegre/ alma que imaginam pintada de preto e vermelho/peixe em geral” (p. 19). Dona Domingas, do Grupo Flor Ribeirinha reforça a ideia de que o cururu é um ritual indígena, mas não necessariamente religioso,

\begin{abstract}
Minha avó, que nasceu aqui (Bairro São Gonçalo Beira rio, na margem esquerda do rio Cuiabá) aqui era uma aldeia Coxiponé ... ela já dançava o siriri... falava que quando morria alguém deles colocava o corpo no centro da aldeia e cantava e dançava um cururu, mas não era só quando morria não... pra festá também. Essa é a verdade; o cururu é rum ritual fúnebre indígena... [Ela ainda se queixou dos pesquisadores que segundo ela escrevem sem saber] os pesquisador escrevem errado... eu sei porque nasci no berço da cultura... aprendi com minha avó ... vovó morreu com 106 anos... era índia.11
\end{abstract}

É de conhecimento através dos documentos históricos, a presença dos índios, Bororo, Coxiponé e outros, nessa região, entretanto, não há, na bibliografia estudada, indicadores que liguem esses nativos, diretamente ao cururu ou ao siriri, todavia, estudos apontam fragmentos plausíveis em que tudo se relaciona. Sobretudo, porque os documentos apontam que foi justamente nesta região, onde Pascoal Moreira Cabral, encontrou os primeiros veios auríferos de Mato Grosso, em 1719, ocasionando o extermínio de várias nações indígenas, culminando na criação da Vila do Cuyabá (SÁ, 1904). De qualquer maneira, Antônio Candido abandona essa ideia, ou a possibilidade de aproximação dessas danças com o cururu. No entanto, considera tanto no registro de Max Schimidt que presenciou a dança entre os Guató e Borôro, no Mato Grosso, quanto no registro de Edmund Döppenschmidt que a observou em região próxima, a afirmação que em ambos "os casos, não pode haver a menor dúvida de que se trata de um traço tomado à cultura cabocla e integrado em cada tribo de acordo com a sua respectiva organização (...) do contato extenso do conquistador e do catequizador com as populações e a cultura Tupi" (p. 40). Reforça a crença de uma dança originalmente ritualística de povos indígenas, considerando a existência de representações místicas sobre a origem do fogo. Reforçando que cururu, na língua tupi significa sapo grande, entre as nações pertencentes ao mesmo tronco linguístico.

De acordo com Candido, após a louvação dos santos iniciam-se os desafios que tanto são da ordem religiosa quanto profana. Uma dança constantemente presente nas festas católicas tradicionais. $\mathrm{O}$ autor assegura que se de um lado, os grupos indígenas incluíram na sua vida religiosa elementos tomados ao

${ }_{11}$ Domingas Leonor. É fundadora do Grupo de Siriri Flor Ribeirinha. A entrevista aconteceu no Quintal da Domingas, no bairro São Gonçalo Beira-Rio (localizado na margem esquerda do rio Cuiabá, região muito frequentada por turistas) sua residência e onde são realizados os encontros e ensaios do grupo, em 09/10/2016. 
cristianismo, de outro, a catequese assumiu certo compromisso com a cultura local e de alguma forma, o que se deu foi a "incorporação de práticas mágicoreligiosas do aborígene à sociedade formada pela catequese e a fusão de raças e culturas" (p. 41). Essa junção se acomodou de tal forma "que o conteúdo foi substituído, aparecendo os santos e as virtudes; ao mesmo tempo ou em seguida, o tema do debate, o relato de feitos e a afirmação pessoal foram se inspirando em elementos sugeridos pela nova situação (...)” (p. 43).

$\mathrm{O}$ autor afirma, que práticas originárias portuguesas incorporaram maior ou menor elementos e que a influência africana só aconteceu a partir do século XVIII, quando estas já haviam se estabelecido, levados pela difusão demográfica provenientes da dominação europeia, sobretudo em Mato Grosso, "o cururu corresponde a essa constelação de elementos, transposta da sociedade tribal e reinterpretada em vista da integração de uma nova sociedade, não primitiva mas rústica" (p. 43).

Cardim (1925), em referência aos costumes dos bailes e cantos tupis, nos $\operatorname{diz}$

\begin{abstract}
Os seus bailos não são diferentes de mudança, mas é um contínuo bater de pés estando quedos, ou andando ao redor e meneando o corpo e cabeça, e tudo fazem por tal compasso, com tanta seriedade, ao som de um cascavel (...) com muitas pedrinhas dentro ou umas certas sementes de que também fazem muito boas contas, e assim bailão cantando; juntamente, porque não fazem uma cousa sem outra, e têm tal compasso e ordem, que ás vezes cem homens bailando e cantando em carreira, enfiados uns detrás dos outros, acabam todos juntamente uma pancada, como se estivessem todos em um lugar; são muito estimados entre eles os cantores (...) se tomam bom cantor e inventor de trovas (p. 175).
\end{abstract}

Sousa (1851) confirma,

\begin{abstract}
Os tupinambás se prezam de grandes músicos, e, ao seu modo, cantam com sofrível tom, os quais têm boas vozes; mas todos cantam por um tom, e os músicos fazem motes de improviso, e suas voltas, que acabam no consoante do mote; um só diz a cantiga, e os outros respondem com o fim do mote, os quais cantam e bailam juntamente numa roda, na qual um tange um tamboril, em que não dobra as pancadas; outros trazem um maracá na mão, que é um cabaço, com umas pedrinhas dentro, com seu cabo por onde pegam; e nos seus bailes não fazem mais mudanças, nem mais continências que bater no chão com um só pé ao som do tamboril; e assim andam todos juntos à roda, e entram pelas casas uns dos outros; onde têm prestes vinho, com que os convidar; e às vezes anda um par de moças cantando entre eles, entre as quais há também mui grandes músicas, e por isso mui estimadas. Entre este gentio são os músicos mui estimados, e por onde quer que vão, são bem agasalhados, e muitos atravessaram já o sertão por entre seus contrários, sem lhes fazerem mal (p. $315)$.
\end{abstract}

Dessas descrições quinhentistas, é possível apontar um conjunto de elementos comuns presentes nas danças indígenas que foram incorporados ou seriam próprios do cururu? Talvez. Conforme aponta Candido, por ser uma dança arrodeada, cuja marcação rítmica se fazia com o pé, a mitologia, a celebração das façanhas, cantos de improviso e os debates poéticos. Inclusive, o ponto alto da dança, estaria na transferência da celebração mitológica, à celebração e louvação aos santos, "o desafio de cururu, na sua forma original, é peça integrante da dança e se enquadra numa estrutura poética mais complexa, precedido pela saudação e a louvação, obedecendo além disso a certos limites de 
decoro devido ao teor religioso" (p. 45). Fato que para o folclorista, apontaria mais propriamente para uma origem indígena do que para o desafio trovadoresco, como sugeriu Chiarini. Segundo o autor, essas diferentes interpretações por si só devem ser consideradas como um conceito de difusão, sobretudo porque "as festas religiosas são intercomunicáveis, e um dos trabalhos prediletos dos mitólogos e folcloristas é justamente pesquisar as sobrevivências pagãs nos festejos cristãos” (p. 40).

Todavia, o cururu de certa forma autônomo, conforme sugere o próprio Antônio Candido, após ter sido a catequese consolidada "incorporou-se de forma espontânea, aos festejos populares de junho, de Pentecostes e do Natal [nesse caso] menos por intervenção jesuítica [mas mais], pelo significado emocional para as populações mamelucas” (p. 18), em Mato Grosso, se difunde como um festejo por si só, fato que pode ser comprovado por ocorrência das prisões dos brincantes reunidos nas rodas de cururu, em dias de semana, sem autorização policial, ou bilhetes dos seus senhores, no caso dos escravos.

Edgar Roquette-Pinto em 1912, fez um importante registro sobre os cantos sertanejos cuiabanos, ocasião que integrou, como convidado, uma expedição cientifica, pelo então territorio do Guaporé, formada pela Comissão Rondon. Com um registro e compilação de mais de 3.000 (três mil) itens, encontram-se entre eles o que seriam os primeiros registros sonoros da música praticada entre os indios Parecis e Nambiquaras, sua importância remonta às grandes expedições cientificas (PEREIRA e PACHECO, 2008, p. 04). Entre essas músicas gravadas, estão três cantos sertanejos cuiabanos acompanhadas por viola de cotcho12 e ganzá. Infelizmente esses registros sonoros se perderam com o desgaste do tempo, mas ao menos é possível ouvi-las a partir das partituras transcritas pelo musicólogo Astolfo Tavares. Apesar de não classificar essas músicas entre o cururu e o siriri, dada a utilização do baixão; oh dan, dan, dan... e dão, dão, dão, é possível asseverar, de acordo com referências já citadas anteriormente nesta tese, que se enquadram em ambas as categorias de danças. Segue a reprodução das letras;

\author{
Dão! dão! dão! \\ O que ôro não arruma \\ Não tem mais arrumação \\ Alecrim a beira d'agua \\ Manjerona d'outra banda é signá de querê bem \\ Oh! dan! dan! \\ Oh! dan! dan!
}

\begin{abstract}
Eu hei de morrê cantando agarrado no meu côtcho
Quando me vê chorando menina é meu amô que vae s’imbora (p.427/8).
\end{abstract}

Em 1978, a pedido da Secretaria Municipal de Educação e Cultura de Cuiabá, alguns pesquisadores fizeram um levantamento das manifestações culturais na região de Cuiabá e baixada cuiabana, cujo trabalho resultou em

\footnotetext{
${ }_{12}$ Roquette-Pinto explica, COTCHO - Voz cuiabanado vocábulo cocho. E' uma viola sertaneja feita a facão, com duas ou quatro cordas de tripa ou de fibras de palmeira, arranjadas com o material da região. Em certos desafios, o cotcho é acompanhado pelo ganzá, espécie de matraca ou récoréco (ROQUETTE-PINTO, 1919. p. 344).
} 
uma série intitulada; Cadernos Cuiabanos. O Caderno N. o8, de responsabilidade de Otávio Ramos e Arnaldo F. Drummond, retrata o perfil socioeconômico dos cantadores e dançadores de cururu e siriri, em Cuiabá. Logo no início do trabalho, os autores trazem impressa a preocupação com relação à sobrevivência desta, que denominam "expressão de arte popular autêntica” (p. 03), em meio ao crescente desenvolvimento urbano por que passa a capital. Apontam a truculência da polícia no início do século XIX, com a prisão de cururueiros em plena função, sem autorização prévia e, fazem uma descrição completa sobre a dança. Uma dança arrodeada, na qual os cantadores giram ritmadamente da esquerda para a direita "dando um passo e parando; dois passos e parando por fração de segundo; depois mais três pequenos passos” (p. 14), para recomeçarem novamente, no ritmo da viola e do ganzá. Em meio a gingados e movimentos corporais os outros dançam entre si. Assim que chega a bandeira, os cantadores ajoelham-se diante do altar arrumado no canto da sala da casa e iniciam a louvação, "a festa é para o santo, pode ser Santo Antônio, São Pedro, Senhor Divino, São Benedito, qualquer um. É o santo da devoção do dono da casa que comemora sua data todos os anos" (p. 12).

Enquanto modalidade de cultura do povo, o cururu sob o aspecto de gênero musical, não conta com autoria individualizada, entretanto, do ponto de vista criativo, atua como projeto individual pautado nas habilidades artísticas de cada membro do grupo, e cabe aqui ressaltar, o papel do cururueiro (tocador de viola-de-cocho), como o principal porta voz do cururu. Sua notoriedade o coloca como figura de grande importância junto a sua comunidade. Desta feita, atrai para si grande distinção, pois executar a viola com destreza enquanto formula os desafio aos companheiros, é sempre visto como algo superior "os cantadores estão avisados. Somente cantador de alguma sabedoria, que brincadeira para o santo precisa ter ciência, tem que saber fazer as saudações, não pode ser na base do lari-lai-á” (p. 12, grifo dos autores). A dupla que inicia a louvação canta com um verso e arremata com a toada, "os versos não têm donos. Podem ser de saudação ao santo, ao dono da casa, ao rei, Rainha e demais figuras do simbolismo (...) Podem ser da tradição ou improvisados de momento. O verso é sempre trovado, rimado. Já a toada, quase nunca tem rima” (p. 13), ao contrário do verso, a toada tem um dono e é sempre respeitada pelos demais cururueiros. Thomas13 explica;

\footnotetext{
Quando tem as festas é no verso que o cururueiro faz a saudação ao santo, aos festeiros, aos amigos, aos companheiros... isso é tudo no verso... ai chega determinado momento da festa que o dono da festa chama o cururueiro e fala para começar o rainhado vamos começar a procissão... ninguém pega o microfone para falar "senhores festeiros vamos formar a procissão" quem faz essa chamada é o mestre cururueiro no verso cantado... seguindo a ordem da roda... quando chega a minha vez eu chamo qualquer um da roda para me ajudar... mas eu improviso o verso chamando os festeiros para se apresentar e assim segue a sequência... a toada é totalmente desvinculada do verso... é de temas variados... pode ser sobre a vida do santo, de Cuiabá, do Estado.
}

\footnotetext{
${ }_{13}$ Thomas Flaviano (nome artístico) é cururueiro e faz parte da diretoria do conselho administrativo da Associação de Cururueiros Tradição Cuiabana do Coxipó. A entrevista foi realizada em uma Escola municipal onde ministra aulas para a educação infantil, no dia 23/03/2017.
} 
Exemplos,

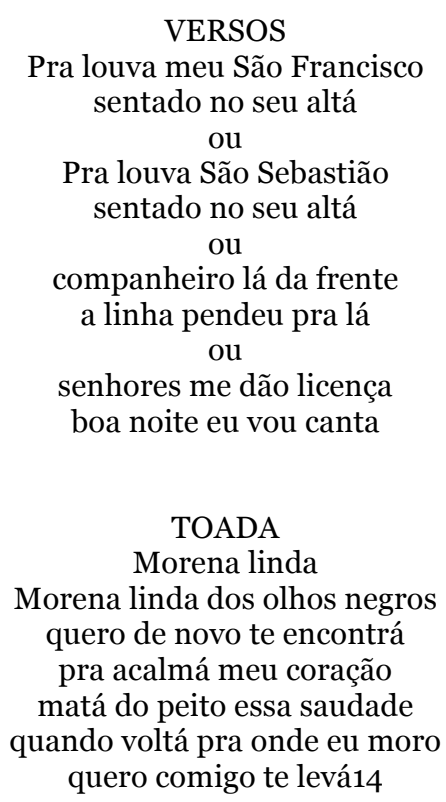

Assim repetem essa sequência diante do altar por três vezes e mudam o verso com uma toada qualquer (no sentido do conteúdo/referência), mas de autoria própria. Todos os cururueiros fazem a saudação, com versos acompanhados das toadas, o ultimo finaliza a saudação e convida os companheiros para rodar, "começou a função" (RAMOS \& DRUMMOND, 1978, p. 14). Os cantadores indicam o momento de levantamento do mastro, o alferes carrega a bandeira, ao rei (festeiro) é entregue a imagem do santo homenageado, os juízes e juízas carregam palmas, velas acesas e imagens de outros santos. Os demais seguem com velas acompanhando os cururueiros que puxam a procissão, "sempre [com] versos, divididos em duas partes e acompanhados de toadas" (p. 16). Cada movimento indica uma ação, essa, sempre através do canto. Após o levantamento do mastro, seguindo ainda a indicação dos cantadores, os cururueiros convocam a rodear o mastro, em seguida voltam-se para o altar para cantar o louvor. O ganzá dá o ritmo, com grande intensidade de som. Cantando versos e toadas os cantadores dão três voltas em torno do mastro e iniciam o retorno à casa "canta-se, anda-se, parase, trocam-se de cantadores, canta-se, anda-se” (p. 16), de volta para casa, os símbolos são recolocados e o cururu continua. Terminada a louvação, inicia-se a função, na qual os cururueiros se divertem com os repentes, que variam entre passagens bíblicas, natureza e amores, momento que exige-se grande habilidade no improviso, "quando um cantador inicia seu verso, ele procura cantar de modo que o seu tema tenha relação com o verso do companheiro que precedeu 
(...) mas a relação, na sequência do Cururu, pode ser dada apenas pelo espirito do novo verso, sem que haja obrigatoriedade de se repetirem as frases" (p. 18). Thomas assegura que "a toada é totalmente desvinculada do verso". A festa pode durar até quatro dias, cantam, dançam, rezam, comem e bebem. Regados à cachaça curtida em raízes, para curar os males da cantoria, segundo a sabedoria popular.

Um traço comum presente nessas abordagens, residiria no fato de que apesar dos relatos sobre o cururu presenciado no Mato Grosso, sobretudo pelos viajantes europeus no século XVIII, estarem sempre carregados de estranhamento, são esses relatos que serviram de base para outros estudos e conceituações. Além do que, esses testemunhos são os principais, originais e inéditos para a compreensão das danças na região, considerando que foram feitas por ocasião de suas próprias observações in loco. Não obstante, é oportuno ressaltar que apesar das divergências entre alguns autores, em todos, a base do cururu estaria de fato, em uma dança circular, frequentemente associadas à práticas rituais indígenas.

Por exemplo, a partir das hipóteses levantadas por Couto de Magalhães, segundo o qual, o cururu teria sido apropriado da cultura indígena e transformado pelos jesuítas, muitos estudos a partir da década de 1940, seguem essa linha de raciocínio.

As referências que Francisco Brasileiro (1951) faz ao cururu em 1947, em sua Monografia Folclórica sobre o Rio das Garças, são possivelmente as primeiras após os relatos de Moutinho, Steinen e Schimidt, sua descrição é de "uma dança de rodas, sem palmas e sem sapateado, com acompanhamento de violas, rabecas e reco-reco" (p. 341). O instrumento que chamou a atenção do folclorista foi o reco-reco, sendo o mais importante, segundo o qual, suas batidas dariam o ritmo da dança e de acordo com o autor, de melodia pobre, mas de grande exigência artística na improvisação dos versos, "é sobretudo na improvisação o maior valor dos versos cantados” (p. 341). São de Brasileiro, as conceituações inseridas no Dicionário do folclore brasileiro de Câmara Cascudo, sobre a dança observada em Cuiabá. A mais conhecida exceção é a de Joao Chiarini em 1947, que supunha ser o cururu um folguedo trazido de Portugal que se misturou à elementos da terra.

Eduardo Escalante (1981) em seus estudos sobre a Festa de Santa Cruz em Carapicuíba, assegura que várias expressões musicais da cultura ibérica se adaptaram a realidade da América Portuguesa, cujas evidências na maioria das vezes se revelam na tradição renovada a cada ano nas festas populares tradicionais, que em devoção à cruz, revivem todo ano a herança de seus antepassados. Não obstante, essas evidências, de alguma maneira apontam o cururu descendente direto das danças tupis, ligado às festas tradicionais portuguesas, sob intervenção jesuítica, incorporadas à cultura popular, senão em sua totalidade, em outras formadas aqui, em áreas de povoamento. Conforme afirma Candido (1956), seguindo um processo de reorganização cultural com forças exercidas ora pelo conquistador, ora pelo conquistado, incorporado como complemento da Dança de Santa Cruz formada por ocasião 
do povoamento e, a Dança de São Gonçalo, aqui reformulada, sob forte apelação devocional.

Desta feita, identificar a natureza dessas festas/danças com suas sutilezas se faz um desafio desde a transição da Idade Média para o Renascimento, acrescidas a essa mistura uma convivência simultânea das diversas línguas/culturas com seus idiomas distintos o que potencializou a problemática no processo de sedimentação e definições terminológicas da língua portuguesa. Todavia, nesses registros feitos há mais de cem anos, percebe-se alguns elementos semelhantes ainda hoje praticados pelos cururueiros matogrossenses. Os movimentos em círculo: volteando os corpos para o lado do braço da viola, ou seja da esquerda para a direita da roda. O cantador: o repentista, cururueiro que trova o repente. Os versos: irregulares e sem rima. $\mathrm{O}$ baixão: bate-rebate dos versos, um canto silábico entoado normalmente em falsete, lara-la-lá, lali-la-lão. Carreira: sequência de rimas com mesmo tema. Festeiro: o responsável pela festa, normalmente de cunho religioso. Função: a representação do cururu. Louvação: saudação aos santos. Repente: versos do improviso. Toada: música que acompanha o cururu.

No cururu mato-grossense de acordo com Thomas, "todos os cururueiros tocam individualmente, ou a viola-de-cocho ou o ganzá, mas cantar só em duplas, que vão alternando... as duplas se revezam no momento da cantoria, independentemente da quantidade na festa".

Os instrumentos que servem de base sonora para o cururu são; a viola-decocho15 e o ganzá16 e, no siriri, acrescenta-se o mocho17.

Siriri

Poucas são as menções ao siriri ou ciriri mato-grossense entre os viajantes estrangeiros. Um importante registro é o de Max Schmidt (1942), cuja descrição serviu de base para estudos entre folcloristas. Uma dança, que segundo o autor, se fazia acompanhar de instrumentos improvisados, como algumas cadeiras cobertas com couro, que eram percutidas como tambores e pratos, tocados ritmicamente com garfos, imitando o caracaxá,

\footnotetext{
Dançarinos e cantores formavam uma roda em que ia constantemente um para o centro a dançar. A dança tinha muitas variações e os movimentos eram cada vez maia rápidos, principalmente no fim, quando os dançarinos já não vinham em par e sim cada um per si. Um rapazola negro, mostrou resistência excecional, mas a sua companheira preta não ficava atrás em flexibilidade (p. 14).
}

\footnotetext{
15 Instrumento de cinco cordas, conquistado a partir da escavação em um tronco inteiriço. Seu processo de construção artesanal, guarda o saber tradicional, cujo registro se encontra no Livro dos Saberes do IPHAN. 2009. 16 Otavio Ramos e Arnaldo Drummond (1978) apresentam o ganzá ou caracachá, na designação antiga. Espécie de reco-reco feito de bambu/ Mario de Andrade (1942) aponta o ganzá como herança africana, instrumento exclusivo de percussão rítmica, trazido nos navios da escravidão.

17 Ernesto Vieira (1899) em seu Diccionario musical, apresenta o mocho como Adufe, espécie de pandeiro antigo mais usualmente utilizados por mulheres em danças e cantos. Distingue-se por ser quadrado, não ter soalhas e ser coberto dos dois lados como um tambor. Sua antiguidade remonta da cultura assíria e representado em escultura das ruinas de Nínive. Os árabes usam desde os tempos imemoriais e dão-lhe o nome daff ou duff (VIEIRA, Op. Cit. p. 36).
} 
Já em Paranatinga, região do vale do Cuiabá, por ocasião de uma festa realizada em homenagem à sua chegada e de sua comitiva, conta que aprendeu seu primeiro verso de "ciriri" (sic) (p.27), com o negro Antônio, seu imediato,

\section{"Primeira cantiga, papudo quer dar \\ Também tenha papo, também quero dar”.}

Há ainda uma menção à dança, em um jornal local, do dia 13 de abril de 1890, Jornal O Matto Grosso - de publicação semanal, em cuja nota o editor faz duras críticas ao então governador provisório, por ter permitido a presença das "ínfimas camadas do povo" nos jardins do palácio, enquanto a elite festava nos salões da residência. Segue a nota: "Ao que parece impróprio do lugar, do promoter e até mesmo altamente ridículo, foram as danças da arraya miúda, cururu, samba, siriri e não sabemos que mais, havidas no jardim, na noite do baile e na seguinte". O editor segue afirmando que estava o "Sr. Marechal Governador sendo agradável com aquela classe de gente que se diverte com tais folguedos", segundo o jornalista, "faltou o decoro de sua posição", pois esse comportamento era considerado uma "exagerada democracia” (1890, p. 03).

O folclorista João Ribeiro (1919) assegura que o siriri é uma dança "generalizada por quase todo o Brasil" (p. 227). Segundo o folclorista, "o ciriri é o nome de um marisco de concha” (p.227). Associa o siriri brasileiro a uma dança portuguesa do século XVIII, por nome otiriri. Sem maiores detalhes sobre essas danças, o autor aponta os vocábulos ciriri, (correr) e otiriri (que fogo, corre) (p.229), que também são dialetos tupi, suficientes para explicar a sua denominação indígena. De acordo com o autor, pode ter havido uma fusão “contínua e ininterrupta transformação" (p. 231), dessas danças.

Francisco Brasileiro (1951), descreve o siriri como uma dança típica dos cuiabanos, que de frente para os violeiros, abrem "uma clareira que é ocupada por um único dançarino que improvisa um sapateado acompanhando o ritmo da música. Depois de certo tempo o figurante se aproxima de um dos circunstantes e com uma mesura tira-o para dançar, e passa por sua vez a espectador” ( $\mathrm{p}$. 343). Palmas e canto, com versos simples, porém amáveis;

\footnotetext{
Alecrim verde arrancado

Chora a terra em que nasceu

Como não hei de chorar

Um amor que já foi meu
}

Rossini Tavares (1957), depois de presenciar a dança em Cáceres, em 1957, cidade distante 215 quilômetros de Cuiabá, em um texto no jornal A gazeta, assim a descreve, "uma dança em que homens e mulheres se organizam em fileiras, frente à frente, o instrumental consiste em tambor e reco-reco, posicionados no centro da fila" e segue sua descrição,

\footnotetext{
Os homens ao som do instrumental, e fazendo-se acompanhar de palmas, cantam o baixão em "ai, lai lai lai”. Logo, terminado este, um cantador joga uma quadrinha, que não demora a ser repetida por todos. E com os instrumentos a tocar, o bater de palmas, um e outro dançador saem a procurar as damas, e com estas eles vêm num dançar cadenciado e sambado, sem lhes tocar as mãos (fl. 505).
} 
Para o autor, a forma de dançar o siriri, não difere muito do Samba de Lenço de São Paulo e, assegura que o siriri é uma modalidade de samba, cuja comprovação seria esta quadrinha;

\author{
Ciriri de Mato Grosso \\ Veio prá esta Capitá \\ Tomá parte no forcrore \\ Marrequinha da lagoa \\ Tuiuiu do pantaná \\ Marrequinha pega o peixe \\ Tuiuiu já vem tomá \\ Ciriri gambá ô lê \\ Ciriri gambá ô lá \\ Desaperte o meu culete \\ Que eu quero é sambá
}

Em sentido oposto, Edson Carneiro, ao escrever para o Diário de Notícias, em 1960, sobre O Ciriri de Cuiabá, afirma a impossibilidade da aproximação da dança com os ritmos africanos. No texto, o pesquisador faz uma crítica às definições de Rossini Tavares e Câmara Cascudo, segundo o folclorista, os elementos apresentados pelo primeiro são insuficientes para que se possa afirmar que o siriri seja uma dança afrodescendente, com relação ao segundo, Carneiro afirma que o mesmo "julgou vislumbrar na descrição de Max Schimdt uma modalidade de samba rural" (p. 3), sem qualquer comprovação presencial. Para o autor "o ciriri é ainda agora dança, tecnicamente baile, essencialmente rural”. Refuta qualquer relação do siriri com as danças africanas e também porque a "pequena população negra de Mato Grosso (...) não guarda proporção quer com a área de propagação, quer com a importância social do ciriri” (fl. 506), para os moradores da região. Ainda de acordo com o folclorista, o fato de estar a viola-de-cocho ligada não só ao siriri, mas ao cururu e o rasqueado, sugerem certa estranheza, já que os batuques, "prescindem dos instrumentos de corda” (id.), acompanhadas ainda do tamborim ou caracaxá, junto com o ganzá, sem esquecer de mencionar os gritos "esganiçados". Ao presenciar a dança em uma região próxima a Cuiabá, afirma que a mesma não se parece com um samba. Para Carneiro, por ser essa, uma região de fronteira e de exploração de garimpos, colonizada pelos portugueses, “a explicação para o ciriri, não estará na África, mas na Europa (...) assim a música e as figurações do ciriri teriam vindo na bagagem dos emigrados, não africanos, mas portugueses, e em Mato Grosso se teriam mesclado e afeiçoado ao cururu local” (ibid.). Seu registro segue, "os dançarinos em roda, alternam as palmas nas palmas ora da esquerda ora da direita, de mãos dadas avançavam para ora para o centro da roda, ora de volta aos seus lugares, sempre com movimentos de giros e balanços, novamente em fileiras, os casais iam se deslocando por entres os outros pares, até o último da fila" (ibid.). Esses dois movimentos, sugere o autor, boa lembrança da cana verde, paulista e o caranguejo dos fandangos do centro-sul brasileiro, incluindo 
outras danças de roda infantis, de origem do sul da Europa. Chama a atenção para o fato de ter o cururu espaço para a improvisação, enquanto o siriri, se reduzir a uma quadra ou sextilha, com o acréscimo de alguns versos, repetidos infinitamente pelos dançantes,

\author{
Adeus \\ Adeus, minina \\ minha flô de laranjeira \\ Eu vô-s'imbora \\ e adeus terra brasileira \\ Eu vô-s'imbora-ô ] ad nausem \\ lá pra frontêra ]
}

Três anos depois, Rossini Tavares (1963), escreve outro texto, esse, em resposta às críticas de Carneiro, intitulado: Análise e interpretação do ciriri mato-grossense, ao qual denomina, Conclusão. Neste, rebate Carneiro e reforça a ideia da descendência africana. Conforme Tavares, o modelo distinto de pergunta-resposta, presente no siriri, é uma característica própria das “danças afro paulistas, principalmente nas modalidades de samba” (fl. 510). Reforça a ideia a partir dos versos recolhidos por Karol Lenko:

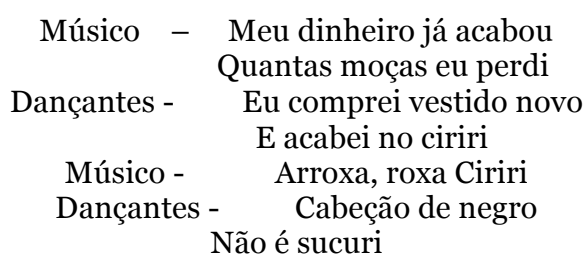

O autor explica que Carneiro não reproduziu “o ritmo do acompanhamento que na verdade é o que caracteriza uma dança, como fenômeno musical” e que sua conclusão é genérica. Reafirma ser uma dança de origem africana, haja visto Schimdt tê-las presenciado entre os negros, cujo instrumental seria um tamborete recoberto com couro de boi e o ganzá, apoiado pelos versos recolhidos por Karol Lenko, reafirmando portanto, sua conclusão de três anos antes.

Julieta de Andrade (2006) e Roberto Loureiro (2006), na busca por uma definição da dança, apresentam opiniões próximas quando enfatizam que as características do siriri, se aproximam de outras danças de elementos mistos, africanos, portugueses e espanhóis. Andrade assim a define; uma dança "hispano-lusitana fortemente aculturada no ritmo e no andamento com a expressão africana bantu” (p. 10). Conforme já afirmara o folclorista Edson Carneiro.

Santos (2010), reforça que o siriri é dançado em pares, com formação em círculo ou fileiras, tendo como movimento básico a coreografia das palmas, batendo as mãos nas mãos dos dançarinos ora da esquerda, ora da direita. Nesse momento de girar a roda, os dançarinos vão respondendo aos tocadores 
(cururueiros), que conduzem o canto. Na formação em fila, se colocam frente à frente, mulheres de um lado, homens de outro, sempre com o movimento de bater as mãos espalmadas nas mãos dos vizinhos. Nesse movimento a dupla que se encontra em uma das extremidades da fila sai dançando por entre a fileira, nos mais variados ritmos e movimentos, seguidos pelos demais até que cada par retorne ao seu lugar de origem. De acordo com a autora, um saber cuja transmissão privilegia essencialmente a oralidade.

Desta feita, é possível inferir que os sujeitos constroem suas histórias baseados em um conhecimento que busca referência nas memórias consagradas pelo tempo como um testemunho transmitido de pai para filho, de uma geração para outra e de um grupo para outro, através da oralidade em um processo ativo e dinâmico. Conforme assegura Lima (2012) "em uma densa e silenciosa trama de memória, aprendizado, transmissão de saberes" (p. 151), cujo registro se faz presente na fala de alguns cururueiros. Seo Marcos garante "eu aprendi a tocar viola com o meu pai, sempre acompanhava ele nas festas, que aprendeu com o pai dele, meu avô", Seo Marcelino afirma "o que eu sei aprendi com meu pai, que aprendeu com o pai dele, seguimos na tradição", Thomas confirma "eu aprendi com meu pai, que aprendeu com o pai dele e se você perguntar para eles (cururueiros) de onde vem, qual a origem do cururu, eles vão dizer "eu não sei, só sei que aprendi com meu pai que aprendeu com pai dele18”, segundo eles, uma tradição indígena, já que todos garantem ser descendentes de índios, quer por parte de mão ou por parte de pai.

Desta forma, construindo e compartilhando memórias, de acordo com Lima (2012) "memórias que o tempo consagrou", em um mesmo espaço geográfico, esses grupos de cururu e siriri, restabelecem o vínculo afetivo dos sujeitos dessas práticas com a comunidade, ao mesmo tempo em que preservam e dão continuidade às suas tradições, as quais "a oralidade torna perene" (id., ibid., p. 151), se reconhecem, reconhecem o mundo e explicam-se a si mesmos.

No que tange as transformações, a inserção desses grupos nos espaços públicos e midiáticos, se faz baseada nos novos discursos adotados pela própria comunidade e seus representantes, que veem a possibilidade de incrementar suas práticas, ampliando seu espaço de circulação. Diante da possibilidade de visibilidade através dos festivais, eventos, circuitos e divulgação eletrônica, Thomas, do Grupo de Cururu Tradição Cuiabana, afirma, "a gente quer ampliar nosso público... os cururueiros nascidos aqui eles acabam vivendo só pra aquilo... então a gente (ele) tem essa consciência de manter, divulgar e inseri isso nas escolas, em palestras e cursos... sempre com respeito mantendo a essência do cururu..." De acordo com Thomas, que recentemente teve a oportunidade de gravar um cururu em estúdio, não basta dar visibilidade apenas, é fundamental assegurar a essência da tradição,

Queremos que o nosso cururu chegue a mais pessoas.... então fomos para um estúdio gravar um cururu... Precisava a gente ter conhecimento do que é cururu e gravação de estúdio e graças a deus eu reunia esses dois conhecimentos... eu conheço a voz dos

${ }^{18}$ Essa entrevista foi realizada no dia 01/04/2017, no Quintal Cultural, sede da Associação de Cururueiros Tradição Cuiabana do Coxipó, atual residência do Sr. Marcelino, presidente da associação. 
cururueiros eu sei que eles falam "vamo" e eu não vou exigir que eles falem "vamos" e vários outros detalhes... mas acho que fosse uma pessoa que não reunisse esses dois conhecimentos poderia ter muita dificuldade e até incorrer em mudanças de características... os cururueiros confiam muito na gente [nele]... meu pai era cururueiro afamado na região [Seo Manoel]... sou formado em música pela Federal [UFMT]... toco viola-de-cocho... componho... tudo isso me dá o aval.

\title{
Ainda nesse contexto, Edilaine do Flor Ribeirinha, defende as mudanças. Como você vê essas mudanças no siriri?
}

\begin{abstract}
(Edilaine)
Algumas pessoas acham que estilizou... o siriri por ser dança de casais teve como mudar... pra mim não foi estilizar o siriri... foi... (pausa)... como eu diria... deu uma glamurada... se a gente não tivesse corrido esse risco de melhorar... melhorar que eu falo é cantar direito para as pessoas entender... melhorar a postura de um dançarino na apresentação... o siriri não tava como tá hoje... já teria desaparecido... quando ocorreu a ideia do festival o siriri já estava morto aqui em Cuiabá... o povo tinha vergonha... eu sou da época do siriri ser vaiado num desfile de 7 de setembro... corria o risco até de leva pedrada... o próprio povo cuiabano morria de vergonha.... o siriri e cururu sofreu muito preconceito... por a gente ver tanto disso acontecer... dos cuiabanos rirem da própria cultura... sua própria raiz19.
\end{abstract}

É a partir dos estudos de Halbwachs (1990), que se pensa a memória em uma dimensão que ultrapassa o individual, posto que as memórias são lembranças que se apoiam umas nas outras e nenhuma acontece afastada do grupo social ao qual o sujeito está inserido. A lembrança como reconhecimento na medida do sentimento já visto e vivido, atua como resgate desses acontecimentos e vivências do passado, tanto um quanto o outro, dependentes de um grupo social. A memória coletiva, por definição, não ultrapassa os limites do grupo, quando determinado período deixa de interessar, na medida em que dois grupos se sucedem, parte dessas memórias são esquecidas pelos grupos subsequentes. Socialmente nesse momento, tem-se a impressão de que de um período a outro tudo é renovado, tradições e perspectivas positivas para o futuro, reaparecem e permanecem nos mesmos grupos, encontrando seu lugar na tradição, ao mesmo tempo dinamizando-a. Ao evocar a memória para se referir ao siriri e ao cururu no presente, construindo seu próprio discurso e transmitindo sua memória enquanto vivência, como descrito nos enunciados, tanto Edilene quanto Thomas, o fazem para fortalecer e complementar o que se sabe, para que esse saber permaneça coletivo. Nesta esfera, ajusta-se o diálogo do indivíduo, primeiro consigo mesmo, em seguida no confronto dos diferentes pontos de vista que coabitam no grupo de referência. Desta forma, Halbwachs acrescenta que é preciso que haja testemunho, para que um fato se perpetue e se torne memória, pois "[é] na memória de um grupo que se destacam as lembranças dos acontecimentos que concernem ao maior número de seus membros e que resultam, quer de sua própria vida, quer de suas relações com o grupo" (p. 45).

\footnotetext{
19 Edilaine Domingas da Silva Albino, é diretora financeira do Grupo de Siriri Flor Ribeirinha e filha da fundadora do referido grupo, Dona Domingas, da comunidade São Gonçalo. Entrevista concedida em 27/o9/2015. No Quintal da Domingas. Comunidade São Gonçalo. Em Cuiabá.
} 
É importante ressaltar o papel de cada ator social e suas representações pessoais inseridas nas representações coletivas. São discursos em que se percebe "a posição que esse agente social assume (ou mesmo aquela posição que gostaria de assumir) no contexto sociocultural da dança" (SANTOS, 2010, p. 97). Todavia, é possível constatar que o contexto do cururu e do siriri na atualidade, continua sendo o de lutas e negociações.

\section{Bibliografia}

AMERICANO do BRASIL, Antônio. Cancioneiro de trovas do Brasil Central. Goiânia: Oriente, $2^{\mathrm{a}}$ ed. 1973.

AMORIM, Humberto. Da península Ibérica medieval ao século XVII: a chegada e a difusão dos cordofones de cordas dedilhadas no Brasil. RJ. Tese DoutoradoUNIRIO. 2015.

ANDRADE, Mário de. Pequena história da música. 2a ed. Martins, S.P. 1942.

Possíveis raízes indígenas de uma dança popular. In: Shaden, Egon. Leituras de etnologia brasileira. São Paulo: Cia Ed. Nacional, 1956.

BALDUS, Herbert. Ensaios de etnologia brasileira. São Paulo: Cia. Ed. Nacional, 1937.

BRASILEIRO, Francisco. Monografia folclórica do Rio das Garças. Separata da Revista do Arquivo. N. CXLIV. São Paulo: Dep. de Cultura, 1951.

CARDIM, Fernão. Tratados da terra e gente do Brasil. Introdução e notas de Baptista Caetano, Capistrano de Abreu, Rodolfo Garcia. Ed. J. Leite \& Cia. Rio de Janeiro. RJ. Brasiliana. 1925.

CARNEIRO, Edison. Ciriri de Cuiabá. Diário de Notícias, Rio de Janeiro, 11 set. 1960.

CAVALCANTE, Maria Laura Viveiros de Castro. Origens para que as quero? Questões para uma investigação sobre a umbanda. In: Reconhecimento: Antropologia, folclore e cultura popular - V. 04 - Rio de Janeiro - 2012.

CERTEAU, Michel de. A Escrita da história. Tradução de Maria de Lourdes Menezes; revisão técnica, Arno Vogel. - Rio de Janeiro: Forense Universitária, 1982.

CHIARINI, João. Cururu. In: Revista do Arquivo Municipal São Paulo. SP: Dep. de Cultura, 1947. Ainda o Cururu. In: Jornal A Gazeta de São Paulo. 1949. Folha

1011. 
ESCALANTE, Eduardo A. A festa de Santa Cruz da aldeia de Carapicuíba no estado de São Paulo. Rio de Janeiro: MEC-SEC/FUNARTE, 1981. http://docvirt.com/docreader.net/DocReader.aspx?bib=Tematico\&PagFis=110 66\&Pesq. Acesso em 06/01/2017.

Análise e interpretação do Ciriri mato-grossense. In: A Gazeta. São

Paulo.

1963.

http://docvirt.com/docreader.net/DocReader.aspx?bib=Tematico\&PagFis=110

66\&Pesq. Acesso em 06/01/2017.

HALBWACHS, Maurice. 1950. A memória coletiva. $2^{\text {a }}$ Edição. Editora Vértice. 1990.

LIMA, Ricardo Gomes, 1950. O povo do Candeal: caminhos da louça de barro. Rio de Janeiro. Aeroplano. 2012.

LIMA, Rossini Tavares de. FOLCLORE - Ciriri de Mato Grosso. In: A Gazeta. São Paulo. 1957. http://docvirt.com/docreader.net/DocReader.aspx?bib=Tematico\&PagFis=110 66\&Pesq. Acesso em 06/01/2017.

LOUREIRO, Roberto. Cultura mato-grossense: festas de santos e outras tradições. Cuiabá: Entrelinhas, 2006.

MAGALHÃES, Basílio. Vocabulário-Língua dos Borôros-Coroados do Estado de Mato Grosso. In: Revista do Instituto Histórico e Geográfico Brasileiro. Tomo 83. Imprensa Nacional. RJ. 1919.

MAGALHÃES, Couto de. O Selvagem. Tipografia da Reforma. RJ. 1876. - $7^{a}$ Conferencia -Tricentenário de Anchieta - Anchieta, as raças e línguas indígenas. São Paulo. 1897.

MOUTINHO, Joaquim Ferreira. Notícia sobre a província de Matto Grosso seguida d'um roteiro da viagem da sua capital à $S$. Paulo. São Paulo: Typographia de Henrique Schroeder. 1869.

NUNES, José Horta. História do saber lexical e constituição de um léxico brasileiro - José Horta Nunes, Margarida Petter. São Paulo-Humnitas. FFLCH/USP. Pontes. 2002.

O MATTO-GROSSO- 15 de abril de 1890. http://memoria.bn.br/DOCREADER/DocReader.aspx?bib=716189\&PagFis=49 \&Pesq=SIRIRI. Acesso em 12/01/2017.

PEREIRA, Edmundo; PACHECO, Gustavo. RONDONIA 1912 - Gravações históricas de Roquette-Pinto. Coleção Documentos Sonoros. Rio de Janeiro: Museu Nacional/UFRJ, 2008.

PIRES, Cornélio. Conversas ao pé-do-fogo. Itu - São Paulo. Ed. Ottoni. 2002.

Musa Caipira - As Estrambóticas Aventuras do Joaquim Bentinho (o Queima-Campo). Edição Comemorativa do CENTENÁRIO de 
nascimento do autor (1884-1984). Tietê (SP): Prefeitura Municipal de Tietê. Patacoadas. Itu, SP: Poemas: Noivo Caipira e Paixão impossível. Ottoni Editora, 2002.

RAMOS, Otávio; DRUMMOND, Arnaldo F. Função do Cururu. Cadernos Cuiabanos - 8. Ed. Planimpress. São Paulo. 1978.

RIBEIRO, João. O folk-lore: estudos de literatura popular. Rio de Janeiro: Jacinto Ribeiro dos Santos, 1919.

RODRIGUES, João Barbosa. 1872-1887. Poranduba amazonense, ou kochiyma-uara porandub. Rio Janeiro. Typ. G. Leuzinger \&Filhos. 1890.

ROQUETTE-PINTO, Edgard. Rondônia. Rio de Janeiro. Imprensa Nacional. $2^{\mathrm{a}}$ Ed. 1919.

SANTOS, Giordana Laura da Silva. O siriri na contemporaneidade em Mato. Grosso: Suas Relações e trocas. - Dissertação (mestrado). Cuiabá: UFMT. 2010.

SCHMIDT, Max. Estudos de etnologia brasileira; peripécias de uma viagem entre 1900 e 1901 e seus resultados etnológicos. São Paulo. Companhia Editora Nacional. 1942.

SOUSA, Gabriel Soares de. Tratado descritivo do Brasil em 1587 - ed. F. A. de Varnhagen, Rio Janeiro. 1851.

STEINEN, Karl von Den. O Brasil central: expedição em 1884 para a exploração do rio Xingú. Companhia Editora Nacional, 1912.

VIEIRA, Ernesto, 1848-1915. Diccionario musical. Ornado com gravuras e exemplos de música - ${ }^{\mathrm{a}}$ ed. - Lisboa. Ed. J.G.Pacini. 1899. 